\title{
Retraction
}

\section{Retracted: A High-Efficiency, Low-Cost Solution for On-Board Power Converters}

\section{Advances in Power Electronics}

Received 15 June 2013; Accepted 15 June 2013

Copyright (c) 2013 Advances in Power Electronics. This is an open access article distributed under the Creative Commons Attribution License, which permits unrestricted use, distribution, and reproduction in any medium, provided the original work is properly cited.

This article has been retracted as it is essentially identical in content with a previously published paper titled "A Demagnetization Circuit for Forward Converters," by G. M. Ponzo, G. Capponi, P. Scalia, and V. Boscaino. This manuscript was published in the Proceedings of the 6th International Conference on Electrical Engineering/Electronics, Computer, Telecommunications and Information Technology, 2009 (ECTI-CON 2009) [1].

\section{References}

[1] V. Boscaino and G. Capponi, "A high-efficiency, low-cost solution for on-board power converters," Advances in Power Electronics, vol. 2012, Article ID 259756, 12 pages, 2012. 